\title{
Pemilihan Presiden Tahun 2016 dan Politik Luar Negeri Amerika Serikat
}

\author{
Program Studi Ilmu Hubungan Internasional \\ Universitas Gadjah Mada \\ Bulaksumur, Yogyakarta 55281, Indonesia \\ nur.rachmat@ugm.ac.id \\ Diserahkan: 20 November 2016, diterima: 17 Januari 2017
}

Nur Rachmat Yuliantoro, Atin Prabandari, Dafri Agussalim

\begin{abstract}
This study is trying to project some trends of U.S. foreign policy based on the results of presidential election in 2016. The United States had recently held presidential election on November 8, 2016. The victory of Republican candidate Donald Trump shocked the world that he defeated Democratic Hillary Clinton, who had excelled in some polls before the election. Various controversies raised by Trump did not prevent him from becoming the president-elect, as the global community soon became concerned with the possibility of the unstable international politics. After describing Clinton and Trump's stand on foreign policy during their campaign, the study will present the results of the presidential election. Trump's foreign policy is expected to show "the great American power," but at the same time his favor of protectionism could threaten international economic cooperations involving the United States. The U.S. could see its image of "world police" reduced, but this would not automatically make the world safer. Under the leadership of Trump, American foreign policy will face many problems and challenges that are not easy to solve. Keywords: the United States, Foreign Policy, Presidential Election. Donald Trump
\end{abstract}

\begin{abstract}
Abstrak
Penelitian ini mencoba untuk memproyeksikan beberapa kecenderungan kebijakan luar negeri Amerika Serikat berdasarkan hasil pemilihan presiden tahun 2016. Amerika Serikat baru saja menyelenggarakan pemilihan presiden pada tanggal 8 November 2016. Kemenangan kandidat Partai Republik, Donald Trump, mengejutkan dunia. la mengalahkan kanditat partai Demokrat Hillary Clinton, yang unggul dalam beberapa jajak pendapat sebelum pemilu. Berbagai kontroversi yang disampaikan oleh Trump tidak mencegahnya memenangkan pemilihan, membuat masyarakat dunia segera menjadi khawatir dengan kemungkinan politik internasional yang kacau. Setelah menggambarkan posisi Clinton dan Trump pada isu luar negeri selama kampanye mereka, studi ini akan menyajikan hasil pemilihan presiden tahun 2016. Kebijakan luar negeri Trump diharapkan menunjukkan "kekuatan besar Amerika," tetapi pada saat yang sama kecenderungan proteksionismenya bisa mengancam kerja sama ekonomi internasional yang melibatkan Amerika Serikat. AS akan melihat bahwa citra "polisi dunia"-nya bisa berkurang, tapi ini tidak akan otomatis membuat dunia lebih aman. Di bawah kepemimpinan Trump, kebijakan luar negeri Amerika akan menghadapi banyak masalah dan tantangan yang tidak mudah untuk dipecahkan. Kata kunci: Amerika Serikat, Politik Luar Negeri, Pemilihan Presiden, Donald Trump
\end{abstract}

\section{PENDAHULUAN}

Sejak awal tahun 2016, perhatian rakyat Amerika Serikat dan juga masyarakat internasional tertuju pada kampanye dan pemilihan pendahuluan di negaranegara bagian Amerika Serikat sebagai bagian dari pemilihan presiden pada bulan November. Terdapat banyak hal yang menarik untuk didiskusikan dan dianalisis terkait dengan kampanye dan pemilihan pendahuluan tersebut. Di antaranya adalah dinamika perolehan jumlah delegasi setiap kandidat yang dihasilkan dari pemilihan pendahuluan, saling serang secara verbal antarkandidat - khususnya di Partai Republik, sampai pada berbagai kontroversi yang dimunculkan oleh milyuner Donald Trump. Sekalipun mengeluarkan banyak pernyataan yang membuat orang bingung atau bahkan marah, ternyata Trump kemudian berhasil mengamankan nominasi Partai Republik saat konvensi di Cleveland.

Kubu Partai Demokrat juga menunjukkan dinamika yang tidak kalah menariknya. Setelah sempat diramaikan oleh beberapa kandidat, persaingan 
terakhir melibatkan mantan Ibu Negara dan Menteri Luar Negeri Hillary Clinton dan Senator dari negara bagian Vermont Bernie Sanders. Orang mungkin tidak menyukai Hillary karena tidak ingin ada politik dinasti lagi setelah Bush (suami Hillary, Bill, adalah presiden ke-42 Amerika Serikat yang memerintah pada periode 1993-2001), tetapi dukungan yang besar dari

kelompok minoritas membuat ia berpeluang menjadi presiden perempuan pertama Amerika Serikat. Di sisi lain, Sanders berupaya membuat perubahan besarbesaran dalam konteks ekonomi dan sosial, tetapi ia dikhawatirkan akan membuat Amerika Serikat yang liberal menjadi negara sosialis demokratik seperti pandangan politiknya. Clinton akhirnya mengalahkan Sanders dalam hal perolehan jumlah delegasi dari pemilihan pendahuluan dan kemudian dinominasikan secara resmi dalam konvensi partai di Philadelphia.

Dalam politik Amerika Serikat, hubungan antara pemilihan presiden dan isu politik luar negeri menunjukkan dinamika yang menarik. Sekalipun banyak pengamat berargumen bahwa politik luar negeri cenderung tidak begitu diperhatikan oleh para pemilih, namun ia merupakan sebuah tema penting di mana hasil pemilihan akan menunjukkan dampak yang signifikan. Peta posisi Clinton dan Trump terhadap politik luar negeri terbaca jelas. Apa yang akan mereka jalankan - jika terpilih sebagai presiden - untuk merespon kebangkitan Cina, situasi di Timur Tengah, hubungan dengan Eropa, regionalisme dan perdagangan internasional, terorisme, dan isu lainnya dalam politik luar negeri menarik untuk dianalisis.

Tulisan ini penting karena mencoba untuk memproyeksikan kecenderungan-kecenderungan pola kebijakan luar negeri Amerika Serikat berdasarkan hasil pemilihan. Apakah pemilih akan memberikan suara lebih banyak kepada Clinton, yang mempunyai pengalaman sangat banyak dalam ranah politik luar negeri? Atau mereka akan lebih memilih Trump, yang berkeinginan "membuat Amerika kembali menjadi bangsa yang besar"? Dalam konteks ini, identifikasi posisi para kandidat terhadap sejumlah isu internasional yang dihadapi oleh Amerika Serikat menjadi penting. Dari identifikasi inilah kami akan menganalisis sejumlah pilihan kebijakan yang bisa diambil oleh pemimpin baru Amerika Serikat untuk merespon situasi internasional yang terus berubah dengan cepat. Dapatlah dikatakan bahwa politik luar negeri Amerika Serikat akan sangat mempengaruhi politik, ekonomi, dan keamanan internasional, khususnya pada situasi di mana kekuatan Amerika disebut-sebut tengah mengalami kemunduran sejak krisis ekonomi 2008 dan kegagalan "perang melawan terorisme" di Irak dan Afghanistan.

\section{KERANGKA PEMIKIRAN}

Telah banyak buku, artikel jurnal, dan laporan penelitian tentang pemilihan presiden Amerika Serikat diterbitkan atau dipresentasikan. Ini tidak lepas dari fakta bahwa sistem politik Amerika Serikat yang cukup stabil merupakan subjek analisis yang berkelanjutan, termasuk bagaimana model dan implementasi pemilihan presidennya, yang sebenarnya cukup rumit. Salah satu tema utama yang diusung oleh literatur adalah kecilnya pengaruh isu politik luar negeri terhadap hasil pemilihan presiden.

Shana Gadarian (2010) menggambarkan kesimpulan umum literatur awal bahwa politik luar negeri tidak memainkan peran yang signifikan terhadap perilaku politik dan, pada gilirannya, pemilihan presiden. Alasan mendasar mengapa pendapat publik dianggap tidak cukup mempengaruhi posisi seorang kandidat presiden adalah asumsi bahwa isu-isu internasional merupakan sesuatu yang rumit dan tidak berkaitan langsung dengan keseharian kehidupan warga. Masyarakat pemilih umumnya tidak mendapatkan informasi yang cukup tentang politik luar negeri. Mereka lebih mengutamakan isu-isu domestik yang secara langsung maupun tidak akan mempengaruhi kualitas hidup mereka, misalnya ekonomi, pajak, pekerjaan, pendidikan, kesehatan, dan hak-hak sipil.

Sejumlah penelitian mengindikasikan bahwa masyarakat pemilih Amerika cenderung mengesampingkan isu politik luar negeri saat mereka harus memberikan suara. Sowmya Anand dan Jon Krosnick (2003) menulis penilaian sejumlah pengamat bahwa publik Amerika jarang ikut terlibat dalam 
pengambilan kebijakan luar negeri dan jarang melihat kepada isu tersebut ketika memberikan suara dalam pemilihan presiden. Anand dan Krosnick meneliti bagaimana masyarakat pemilih pada pemilihan presiden tahun 2000 tampak cenderung tidak sejalan dengan sebagian besar isu yang dipercaya oleh kandidat, termasuk politik luar negeri, apalagi bila terdapat kandidat yang posisinya berseberangan dengan opini publik yang luas. Meski demikian, ketika isu politik luar negeri menjadi isu yang salient seperti pada pemilihan presiden tahun 2004, peran pentingnya dalam menentukan hasil pemilihan tidak bisa dikesampingkan.

Tentang kecenderungan korelasi yang tidak sejalan antara posisi politik luar negeri para kandidat dan preferensi para pemilih, John Aldrich, John Sullivan, dan Eugene Borgida (1989) menyampaikan temuan sebaliknya. Mereka berargumen bahwa isu politik luar negeri dan keamanan telah mempengaruhi preferensi dan suara para pemilih. Masyarakat pemilih dinilai telah mempunyai sikap tentang politik luar negeri, mampu membedakan dengan jelas preferensi partaipartai dan kandidat-kandidat tentang isu tersebut, dan kemudian menggunakan sikap dan kemampuan tersebut untuk memberikan suara dalam pemilihan presiden. Dengan ini, Aldrich, Sullivan dan Borgida menegaskan bahwa kandidat presiden yang memainkan isu politik luar negeri dalam kampanyenya "do not waltz before a blind audience [when discussing foreign policy]." (p. 135).

Argumen bahwa isu politik luar negeri tidak memainkan peran penting dalam pemilihan presiden di Amerika Serikat juga dibantah oleh hasil penelitian Christopher Randolph, Jr (2006). Randolph menegaskan bahwa para pemilih menunjukkan mereka mempertimbangkan pula posisi kandidat dalam politik luar negeri. Kandidat yang cenderung menunjukkan kebijakan luar negeri yang tidak populer berisiko kehilangan dukungan yang signifikan. Yang menarik, kandidat petahana (dalam kasus ini, Presiden Ronald Reagan) memodifikasi pandangan politik luar negerinya demi mengamankan peluang untuk dapat terpilih kembali. ${ }^{1}$ Rundolph kemudian menyimpulkan bahwa kasus Reagan tidak saja menunjukkan pentingnya isu politik luar negeri dalam pemilihan presiden, tetapi juga bahwa pendapat masyarakat dan isu politik domestik turut menentukan hasil pemilihan tersebut. Kebijakan yang tidak populer akan membuat seorang presiden kehilangan dukungan Kongres dan mengundang musuh yang berpotensi merusak kesempatannya untuk terpilih kembali di masa jabatan kedua.

Jauh sebelum Randolph, Miroslav Nincic and Barbara Hinckley (1991) juga memberikan argumen yang serupa, yaitu bahwa pendapat keseluruhan pemilih atas sikap seorang kandidat dipengaruhi antara lain oleh posisi politik luar negerinya, sebuah situasi yang membuat posisi politik luar negeri memberikan dampak yang penting bagi perolehan suara kandidat dalam pemilihan presiden. Pendapat ini juga didukung oleh David Karol dan Edward Miguel (2007). Karol dan Miguel menunjukkan bahwa Perang Irak telah secara langsung mengurangi jumlah suara yang didapatkan oleh kandidat petahana Presiden George W. Bush. Mereka menemukan bahwa suara untuk Bush bisa saja 2\% lebih besar dari yang nyatanya ia peroleh bila tidak ada informasi bahwa sampai dengan hari pemilihan telah setidaknya 10 ribu tentara dan warga sipil Amerika meninggal dan terluka dalam perang Irak. Dalam artikel ini dapat dipahami dengan jelas bahwa dalam pemilihan presiden tahun 2004, politik luar negeri mempengaruhi hasil pemilihan.

Kebanyakan literatur yang direviu dalam penelitian ini telah menunjukkan bahwa pada tingkat dan kasus tertentu, terdapat hubungan positif antara posisi politik luar negeri kandidat presiden dan hasil perolehan suara yang mereka peroleh. Tema ini merupakan sebuah subjek penelitian yang baik, namun bukanlah fokus utama dari penelitian ini. Dengan argumen bahwa posisi para kandidat sangat menentukan hasil pemilihan presiden pada bulan November 2016, penelitian ini akan mencoba melihat proyeksi politik luar negeri Amerika Serikat berdasarkan posisi kandidat yang keluar sebagai pemenang pemilihan.

Terdapat sejumlah teori yang menjelaskan mengapa 
pemilih memberikan suara kepada kandidat tertentu. Dalam politik Amerika Serikat, salah satu penjelasan ditawarkan oleh Jennifer Merolla, Jennifer Ramos, dan Elizabeth Zechmeister (2007) - menempatkan karisma seorang pemimpin yang dihubungkan dengan situasi krisis yang dihadapi. Merolla, Ramos, dan Zechmeister menemukan bahwa situasi krisis, alih-alih normal, dapat menunjukkan kualitas kepemimpinan seseorang yang karismatis. Menurut mereka, "during times of crisis, individuals look for a strong, confident leader, and they project additional power, morality, and competence onto that individual." (p. 39).

Dalam artikel mereka, Merolla, Ramos, dan Zechmeister menunjukkan bahwa salah satu krisis yang tengah dihadapi Amerika Serikat pada masa itu adalah krisis keamanan nasional: pemilihan presiden dilangsungkan tiga tahun setelah serangan teorisme pada 9 September 2001, sebuah insiden yang digambarkan oleh Wakil Presiden Dick Cheney sebagai hal-hal yang "tidak ingin Anda pikirkan". Kebijakan anti-terorisme Amerika Serikat kemudian dilangsungkan secara total dengan, antara lain, berperang melawan Taliban di Afghanistan dan rezim Saddam Hussein di Irak. Secara tidak langsung ini menunjukkan bahwa isu politik luar negeri memainkan peran penting dalam kecenderungan mayoritas pemilih untuk memberikan suara kepada kandidat petahana Presiden Bush daripada Senator John Kerry. Dukungan luas masyarakat pemilih untuk jabatan kedua juga dimanfaatkan Bush untuk menjalankan kebijakan domestik yang keras sebagai bagian dari anti-terorisme, yaitu program "pengawasan teroris” yang membolehkan agen-agen pemerintah melakukan penyadapan tanpa ijin terhadap target yang dicurigai (p. 40).

Gadarian (2010) mengonfirmasi temuan Merolla, Ramos, dan Zechmeister. Menggunakan data set pemilihan presiden dari tahun 1980 hingga 2004, Gadarian menunjukkan bahwa isu politik luar negeri merupakan salah satu penentu kecenderungan pemberian suara oleh para pemilih. Ia menemukan bahwa dalam situasi yang "mengancam" pemilih cenderung mengidentikkan diri mereka dengan kandidat dan partai politik yang "hawkish" daripada yang "dovish" ("elang" dan "merpati,"

merepresentasikan perang dan damai). Ia juga berargumen bahwa dalam isu politik luar negeri, pemilih Amerika Serikat cenderung akan memberikan suara bukan kepada kandidat yang dinilai akan menjalankan kebijakan yang sesuai dengan preferensi mereka, tetapi kepada kandidat yang dianggap dapat memimpin dengan tegas serta memberikan rasa aman dan perlindungan. Para kandidat pemilihan presiden di tahun 2004 memahami hal ini ketika mereka menggunakan seluruh debat sebelum pemilihan untuk isu politik luar negeri, khususnya tentang terorisme dan perang Irak. Sekalipun isu keamanan nasional dan politik luar negeri secara tradisional dinilai sebagai “isunya Partai Republik," (Gadarian, 2010: 1046) tetapi fakta bahwa kedua kandidat dari dua partai utama "memainkan" isu politik luar negeri secara dominan menunjukkan bahwa, setidaknya dalam pemilihan tahun 2004, politik luar negeri akan menentukan hasil pemilihan presiden.

Ketika sebuah bangsa menghadapi ancaman keamanan nasional dan krisis politik luar negeri, calon pemimpin yang menunjukkan postur politik luar negeri yang "lebih militan" dan "lebih hawkish" cenderung akan mendapatkan dukungan politik yang lebih besar. "Kekuatan" dan "kemampuan menyelesaikan" adalah faktor-faktor penting dalam keputusan para pemilih memberikan suara mereka hal yang menerangkan bahwa pemimpin dengan kualitas tersebut, misalnya Franklin Roosevelt dan George W. Bush, dapat terpilih kembali di masa krisis (Gadarian, 2010: 1049-1050). Dalam pemilihan presiden tahun 2004, isu seperti belanja militer, terorisme, dan perang Irak adalah "isu favorit" Bush yang tidak bisa dihindari oleh Kerry mengingat situasi krisis yang tengah dihadapi Amerika Serikat. Bush kemudian berhasil membuktikan bahwa ia adalah pemimpin yang kuat, yang "melawan teroris dengan segala upaya" dan kemauan untuk menggunakan kekuatan militer untuk menyelesaikan persoalan keamanan nasional dan politik luar negeri (p. 10601061). Pemilihan tahun 2004 telah menunjukan 
bahwa kandidat yang berhasil menunjukkan postur sebagai pemimpin yang kuat dipandang akan lebih berhasil memimpin Amerika Serikat dalam mengarungi krisis dan mengatasi masalah. Pemilihan tahun 2016, dalam banyak hal, merefleksikan pandangan ini.

\section{HASIL DAN PEMBAHASAN}

\section{POSISI POLITIK LUAR NEGERI KANDIDAT PARTAI UTAMA}

\section{Hillary Clinton}

Hillary Clinton, yang menjadi first lady ketika suaminya Bill menjadi presiden selama delapan tahun, pernah menjabat sebagai Secretary of State atau Menteri Luar Negeri pada masa pemerintahan pertama Barack Obama (2009-2013). Untuk strategi kampanye, Clinton sangat mengedepankan pengalaman politiknya. Misalnya, ia berulang kali menekankan pengalamannya sebagai menteri luar negeri dalam merespon isu-isu internasional hingga membandingkannya dengan pengalaman politik kandidat Republik Donald Trump yang dinilai masih sangat kurang (NPR, 2016a). Dengan slogan "Grandmothers Know Best," Clinton juga menggunakan isu gender untuk mendulang dukungan sebagai kandidat presiden perempuan pertama Amerika Serikat. Tiga slogan lain yang ia gunakan dalam berkampanye adalah "Hillary for America", "I'm with Her" dan "We are Stronger Together."

Dalam urusan kebijakan luar negeri, Clinton sangat menekankan pada kekuatan (power), hegemoni, dan keamanan nasional. Sepak terjang Clinton dari saat menjadi senator hingga menteri luar negeri menunjukkan betapa ia cenderung menyukai penggunaan militer dan perang dalam kebijakan luar negeri Amerika Serikat. Dalam artikelnya di laman Foreign Policy, Micah Zenko (2016) membuat suatu analisis menarik bahwa sepanjang karir politiknya sejak tahun 1994, Clinton dapat dipastikan mendukung dan membuat kebijakan luar negeri yang mendukung perang dan intervensionis. ${ }^{2}$

Clinton sangat pro pasar bebas dan melihat bahwa isolasi atau menutup diri dari persaingan internasional bukanlah kebijakan yang sesuai dengan semangat
Amerika Serikat. Namun demikian, Clinton juga menyeimbangkan pandangannya dengan mengatakan akan mendukung setiap usaha untuk mengurangi pengaruh negatif Cina dan melindungi pekerja Amerika di pasar global. Namun, terdapat satu hal yang mengejutkan dari Clinton, yaitu penolakannya terhadap Kemitraan Asia-Pasifik (Trans Pacific Partnership). Clinton secara terang-terangan mengatakan bahwa ia tidak bisa mendukung TPP karena "the bar here is very high and, based on what I have seen, I don't believe this agreement has met it." (Clinton, 2015a).

Clinton memastikan bahwa politik luar negeri Amerika Serikat akan mengedepankan perlindungan hak asasi manusia dengan memprioritaskan berbagai isu seperti same-sex marriage, kesetaraan gender, dan hak anak. Ia juga menekankan akan melindungi kaum Muslim Amerika, yang selalu mendapatkan stereotip buruk akibat dari peristiwa 9/11 dan mengatakan bahwa Muslim Amerika berkontribusi dengan bekerja setiap hari di garis depan melawan radikalisasi. Clinton mengusulkan pembentukan zona aman pengungsi yang bisa menghentikan krisis migrasi ditetapkan sebagai "Doktrin Hillary." Ia pun siap memimpin komunitas internasional dalam mengorganisir penyelamatan dan perlindungan para pengungsi agar hidup mereka aman (Beckwith, 2015; Stacey, 2016).

Di Timur Tengah, Clinton berpikiran bahwa melindungi dan mendukung segala kepentingan Israel merupakan suatu "kewajiban moral" bagi Amerika Serikat (Jewish Telegraphic Agency, 2016). Menanggapi isu nuklir Iran, Clinton mendukung penuh bahwa Iran tidak akan dibiarkan untuk memperoleh senjata nuklir; Amerika dan Israel akan lebih aman apabila memiliki kesepakatan dengan Iran mengenai proliferasi nuklir serta menyiapkan strategi untuk mengantisipasi perilaku buruk Iran di wilayah tersebut secara luas (Clinton, 2015b). Akan halnya konflik di Suriah, Clinton mungkin akan membantu membentuk operasi penjaga perdamaian terbesar PBB. Clinton mengatakan akan mencegah apa yang dikenal sebagai "Negara Islam"/ISIS dari memperkuat pengaruhnya dan akan mendukung suatu transisi pemerintahan yang 
stabil dan sukses (Stacey, 2016). Mengalahkan ISIS di Suriah, Irak, dan seluruh Timur Tengah, mengganggu serta membongkar infrastruktur dan dukungan finansial teroris inilah yang akan menjadi target Clinton (Beckwith, 2015).

Eropa merupakan salah satu tantangan utama kebijakan luar negeri AS, khususnya mengingat di dalamnya terdapat isu Rusia. Sebuah analisis menyebutkan bahwa Clinton mungkin akan mengambil sikap tegas terhadap Rusia dalam persoalan Ukraina, di mana mempersenjatai militer Ukraina merupakan salah satu opsi kebijakan yang sangat mungkin ia ambil. Clinton diprediksikan akan mendukung penguatan kehadiran militer Amerika di Eropa untuk mencegah Rusia memperluas agresinya (Nechepurenko, 2015).

Saat menjabat menteri luar negeri, Clinton pernah mengeluarkan strategi 'Pivoting to Asia,' di mana Amerika Serikat mengakui arti penting Asia dalam konstelasi global dan ingin lebih memprioritaskan kawasan Asia dalam kebijakan luar negerinya. Strategi regional Amerika Serikat yang dilaksanakan oleh Clinton adalah berupa memperjelas komitmen berkelanjutan dalam upaya membentuk suatu kerja sama regional dengan Asia-Pasifik (Clinton, 2011). Kerja sama regional ini merupakan satu dari tiga strategi rebalancing Clinton di Asia - dua yang lain adalah pembangunan kepercayaan antara Cina dan Amerika Serikat serta komitmen penuh untuk memperluas ekonomi, politik, dan kerja sama keamanan secara maksimal. Menanggapi sikap Cina di Laut Cina Selatan, Clinton menyatakan bahwa "the United States, like every nation, has a national interest in freedom of navigation, open access to Asia's maritime commons, and respect for international law in the South China Sea" (Putz, 2015).

\section{Donald Trump}

Di kubu lawan, bergema slogan kampanye "Make America Great Again" dari Donald Trump yang sesuai dengan visi dan misi kepemimpinannya. Perbaikan sistem di dalam negeri dan restorasi kekuatan hegemoni Amerika Serikat di level dunia merupakan kunci kampanye Trump untuk menarik massa, khususnya warga Amerika konservatif yang akhir-akhir ini memiliki keresahan terhadap imigrasi dan terorisme. Secara langsung Trump merespon isu-isu tersebut dan menyatakan posisinya yang kontroversial. Banyak pidato Trump yang mengandung substansi kekerasan dan rasisme. Pernyataannya mengenai isu terorisme dan Islam "radikal", misalnya, direspon negatif oleh kalangan muslim di Amerika Serikat dan dunia internasional. Trump cenderung vokal terhadap isu Islam "radikal" dan terorisme, bahkan sampai ia berjanji untuk tidak hanya membatasi, tetapi melarang masuknya imigran yang berasal dari negara-negara Islam yang diduga menjadi asal terorisme (Berman, 2015).

Di antara fokus kebijakan yang menjadi prioritas Trump mengenai keamanan nasional adalah pengetatan peraturan tentang imigran ilegal melalui program pembangunan dinding yang akan dibangun sepanjang perbatasan dengan Meksiko. Menurut Trump, rencana kebijakan tersebut akan secara drastis mengurangi tingkat kejahatan di AS, seperti penyelundupan yang dilakukan oleh kartel narkotika dan tindak kriminal lainnya, termasuk kekerasan dan pemerkosaan yang dianggap bersumber dari meningkatnya angka imigran yang masuk melewati perbatasan secara ilegal. Mengingat lapangan pekerjaan selama ini didominasi oleh kaum pekerja yang berlatar belakang imigran, maka menurut Trump pengetatan sistem imigrasi akan membuat angka pengangguran di Amerika menurun. Tak pelak, rencana kebijakan imigrasi ini menimbulkan polemik, khususnya di antara imigran Hispanik yang menganggap Trump secara tidak langsung menilai mereka sebagai sumber permasalahan yang dialami Amerika selama ini.

Trump pertama kali mengeluarkan pernyataan tentang kebijakan luar negeri saat menghadiri undangan Center for the National Interest di Washington, D.C., April 2016. Trump memfokuskan beberapa postur kebijakan luar negeri yang menurutnya ideal bagi Amerika Serikat, sesuai dengan slogan kampanyenya yang bertujuan untuk membuat Amerika kembali disegani di kancah politik dunia. Trump kemudian mengatakan bahwa ia akan mengaplikasikan 
"America First" dalam kebijakan luar negerinya (Beckwith, 2016). "America First" yang dimaksudkan oleh Trump adalah memprioritaskan warga Amerika Serikat dan keamanannya terkait dengan kebijakan luar negeri. Trump mengatakan bahwa warga AS menjadi prioritas di dalam setiap keputusan kebijakan luar negeri ketika dia kelak menjadi presiden (Milbank, 2016). "American First" akan menjadi tema utama dalam pemerintahan Trump kelak (Diamond \& Collison, 2016).

Selanjutnya Trump mengkritik intervensi administrasi Obama di Irak, Suriah, dan Libya untuk "mengubah rezim" yang kemudian menyebabkan kekacauan di Timur Tengah. Keadaan ini dianggap memberikan ruang bagi ISIS untuk berkembang pesat. Meskipun tidak bersedia menceritakan kapan dan dengan cara apa, Trump berencana untuk menyerang dan mendeklarasikan perang melawan ISIS. ISIS menjadi "bulan-bulanan" Trump sepanjang kampanyenya menuju Gedung Putih.

Yang pertama kali akan dilakukan Trump dalam menghadapi persoalan politik luar negeri adalah membangun kembali kekuatan militer dan mengembalikan kebebasan sistem finansial negara. Salah satu koreksi dari Trump mengenai restrukturisasi pengeluaran dalam sektor militer mengarah pada peran AS yang ikut andil untuk perlindungan Eropa melalui North Atlantic Treaty Organization (NATO). NATO merupakan salah satu pakta pertahanan paling efektif setelah usainya Perang Dingin dan bertujuan untuk meredam kekuatan Soviet/Rusia. Di dalam pakta pertahanan ini Amerika Serikat menjadi kontributor dana langsung terbesar, yaitu sekitar 22\% dari keseluruhan pendanaan (Kessler, 2016). Trump mengatakan pembahasan baru akan diadakan bersama dengan sekutu-sekutu AS di NATO demi

mempertajam lagi struktur organisasi pakta pertahanan ini serta membahas penyeimbangan pendanaan oleh AS. Menurut Trump, negara anggota lain harus ikut andil dalam pendanaan NATO atau AS tidak akan berusaha mempertahankan mereka jika ada serangan dari kekuatan luar.

Kontroversi lain dari Trump menyangkut kepemilikan senjata nuklir. Penyebaran penggunan senjata nuklir dalam bentuk apa pun, apalagi disalahgunakan untuk terorisme, merupakan hal yang tidak dapat ditolerir. Namun, Trump secara mencengangkan memberikan pernyataan untuk membiarkan Jepang dan Korea Selatan untuk mengembangkan kekuatan nuklir mereka (Kleiner, 2016). Ia juga menyuarakan janjinya untuk "akur" dengan Cina dan Rusia jika terpilih menjadi presiden. Milyuner berusia 70 tahun itu menambahkan, jika dirinya terpilih menjadi presiden maka AS, Rusia, dan Cina pasti akan akur, karena masing-masing presiden memiliki kharisma yang membuat mereka saling menghormati. Trump menyampaikan kritik pedas terhadap kebijakan luar negeri Obama terhadap kedua negara ini. Ia mengatakan bahwa sang presiden telah membiarkan Cina mengambil keuntungan dari Amerika Serikat dan telah gagal untuk mengalahkan ISIS. Menilai banyak yang keliru dari politik luar negeri Obama, Trump berjanji untuk "mengguncang karat dari kebijakan luar negeri Amerika” (Brunnstorm, dkk, 2016).

\section{ISU DEBAT KANDIDAT DAN PELAKSANAAN PEMILU PRESIDEN 2016}

Seperti biasa, dalam minggu-minggu terakhir menjelang pemilihan, diselenggarakanlah debat antar kandidat presiden. Salah satu dari tiga debat yang dilaksanakan pada tahun 2016 ini mengambil tema utama politik luar negeri Amerika Serikat. Isu-isu yang dibahas dalam debat tersebut khususnya menyangkut keamanan nasional, ekonomi dan perdagangan internasional, serta hubungan bilateral Amerika Serikat dengan negara lain.

Merespon permasalahan ekonomi yang dianggap semakin mengkhawatirkan pasca krisis finansial global 2008, Clinton mengajukan strategi untuk memperkuat ekonomi yang adil dan merata, terutama membenahi sistem ekonomi domestik yang dianggap masih terlalu berpihak pada masyarakat kelas atas dan korporat. Sedangkan menurut Trump, penyebab utama melemahnya perekonomian Amerika Serikat adalah kebijakan Cina yang mendevaluasi mata uang, 
sekalipun fakta yang ada terjadi sebaliknya. Selain itu, Trump juga menyatakan perlunya pemerintah Amerika Serikat menegosiasikan kembali kerja sama perdagangan yang telah dibentuk dengan negara lain, misalnya NAFTA, yang ia anggap sebagai sebuah kesepakatan yang "cacat" (NPR, 2016b).

Isu kerja sama perdagangan juga menjadi penting dengan ramainya perdebatan oleh publik Amerika Serikat mengenai Trans Pacific Partnership (TPP) di tengah defisit perdagangan yang begitu tinggi - di tahun 2015, misalnya, angka defisit telah mencapai \$531,5 milyar (NPR, 2016c). Kedua kandidat berpendapat bahwa TPP tidak akan memberikan keuntungan ekonomi, tetapi malah semakin merugikan perekonomian domestik berhadapan dengan negara ekonomi besar seperti Cina. Sekalipun demikian, Peterson Institute for International Economics mencatat bahwa rencana Trump untuk menaikan tarif impor dari Cina dan Meksiko akan menimbulkan trade war yang berpotensi menimbulkan empat juta pengangguran dan resesi ekonomi, serta penundaan pelaksanaan TPP akan menurunkan GDP Amerika Serikat hingga puluhan milyar dolar tiap tahunnya (Noland, dkk, 2016).

Isu lain yang diangkat dalam debat adalah keamanan nasional, terutama tentang kejahatan dunia maya yang mulai marak terjadi di tengah kemajuan teknologi dan upaya menghentikan terorisme oleh ISIS. Trump berpendapat bahwa kejahatan dunia maya adalah masalah sangat besar bagi AS, sedangkan Clinton mengangkat hubungan bilateral dengan Rusia yang tengah renggang akibat rumor serangan dunia maya yang dilakukan oleh peretas-peretas dari negara tersebut (DHS Press Office, 2016). Penanganan kejahatan dunia maya menjadi penting karena banyak organisasi teroris kini menggunakan internet sebagai salah satu alat dalam melaksanakan kegiatan mereka.

Clinton mendorong kerja sama dan hubungan aliansi yang lebih erat dengan NATO dan berkoalisi dengan negara mayoritas Muslim di Timur Tengah untuk mendapat asistensi dalam melawan ISIS. Clinton menunjukkan dukungan terhadap kesepakatan nuklir dengan Iran, namun rencananya untuk membuat "no-fly zone" di Suriah bisa berekskalasi menjadi perang (NPR, 2016c). Sementara itu, strategi yang diajukan oleh Trump dalam melawan ISIS adalah "taking the oil," di mana Amerika Serikat mengambil alih penguasaan ISIS terhadap sumber minyak di Timur Tengah yang berarti memotong sumber dana bagi organisasi teroris tersebut. Tidak jelas strategi militer atau diplomasi seperti apa yang akan dilakukan Trump untuk menghentikan bencana kemanusiaan di Suriah. Trump kemudian mengkritik Jepang, Korea Selatan, dan NATO yang dianggap tidak banyak berkontribusi dan membebankan tanggung jawab hanya pada Amerika Serikat saja. Dapat disimpulkan bahwa Trump tidak ingin Amerika Serikat menjadi "polisi dunia" seterusnya. Clinton, di sisi lain, masih menghargai hubungan aliansi Amerika Serikat dan mengutamakan perdamaian melalui diplomasi (NPR, 2016b).

Isu imigrasi juga kemudian dikaitkan dengan keamanan nasional. Amerika Serikat sering menjadi tujuan bagi imigran ilegal dari negara tetangga, seperti Meksiko, yang kemudian menimbulkan permasalahan sosial atau masuknya banyak pencari suaka dan pengungsi (terutama Muslim) dari daerah rawan konflik yang berpotensi menimbulkan ancaman keamanan. Kebijakan pemerintahan Obama menerima 12.000 pengungsi dari Suriah selama tahun 2015 dikritik oleh Trump sebagai gegabah karena pemeriksaan latar belakang yang dilakukan pemerintah begitu minim dan dapat memperbesar masuknya kriminal dan teroris ke Amerika Serikat. Trump mendorong peningkatan jumlah imigran yang dideportasi serta pemeriksaan yang lebih ketat bagi imigran yang ingin tinggal di Amerika (NPR, 2016c). Sekalipun sepakat dengan ide Trump memperketat perbatasan, Clinton mendukung kebijakan imigrasi Obama yang akan memproteksi sekitar lima juta imigran ilegal dari deportasi dan menawarkan ijin bekerja bagi mereka, terkecuali bagi imigran yang terbukti melakukan pelanggaran hukum.

Secara umum, kedua kandidat memiliki perbedaan pendapat mengenai berbagai isu politik luar negeri. Hal ini mendapatkan respon beragam dari masyarakat, 
namun melalui jajak pendapat yang dilakukan berbagai media independen, Clinton dipandang menunjukkan performa yang lebih baik daripada Trump. Gallup melaporkan setidaknya dua pertiga perempuan yang menyaksikan debat menilai Clinton memenangkan debat atas Trump, sedangkan kelompok laki-laki juga memilih Clinton dengan rasio 54\% melawan 35\% yang memilih Trump (Saad, 2016). Hal serupa juga ditunjukkan oleh jajak pendapat oleh media lain seperti Vox, The Economist, dan CNN.

Keunggulan Clinton dalam banyak jajak pendapat perlahan berkurang seminggu jelang pemilihan, ketika FBI mengumumkan akan kembali membuka investigasi atas penggunaan email pribadi Clinton untuk urusan pekerjaan. Trump, yang mendapatkan keuntungan besar dari situasi ini, kemudian berhasil membalikkan prediksi banyak orang. Sekalipun mendapatkan jumlah popular vote (suara rakyat pemilih langsung) yang lebih sedikit dari Clinton (Trump 61.201.031, Clinton 62.523.126 - data sampai dengan 18 November 2016), namun Trump berhasil mengantongi lebih banyak electoral vote (suara pemilih presiden). Hanya membutuhkan 270 untuk menang, Trump berhasil mengumpulkan 290 electoral vote setelah memenangkan beberapa negara bagian penting, sementara Clinton memperoleh 232 electoral vote (CNN, 2016). Kontroversi dan kurangnya pengalaman Trump tidak menjadikan ia sebagai pecundang. Bahkan, salah satu argumen terkuat yang mencoba menjawab mengapa Trump bisa menang menunjuk pada karakternya yang terbuka, bicara apa adanya, termasuk janji kembali membangun ekonomi Amerika. Ini dilihat oleh para pemilih Trump sebagai ciri-ciri pemimpin "karismatis," pemimpin yang kuat, yang bisa membawa Amerika keluar dari krisis mengafirmasi pendapat Merolla, Ramos, dan Zechmeister tentang pemimpin yang kuat dalam situasi krisis.

PROYEKSI POLITIK LUAR NEGERI DONALD TRUMP:

SEJUMLAH ISU TERPILIH

Keunggulan Amerika

Slogan "Make America Great Again" mengindikasikan keyakinan Trump atas keunggulan Amerika (American primacy). Dalam pandangan Trump, kepentingan nasional Amerika haruslah menjadi yang paling utama. Karena diplomasi merupakan zero sum game, di mana hanya ada satu pemenang dan satu pecundang, Trump berpendapat bahwa penting bagi Amerika untuk kembali mendapatkan penghormatan yang seharusnya dari dunia internasional, dengan cara menunjukan dominasi total atas semua negara. Untuk kembali menjadi negara yang mampu mendominasi, Amerika haruslah memfokuskan diri untuk membangun kekuatan dengan menempatkan kepentingan nasional dan kemampuan negara untuk bertindak tanpa pembatasan dari aliansi maupun aturan internasional sebagai prioritas utama (Beckwith, 2016).

Secara langsung arah politik luar negeri Trump merupakan bentuk anti-hegemoni dan antimultilateralisme yang telah dibangun sebelumnya. Trump melihat hegemoni Amerika kini tidak lagi dapat memberikan manfaat bagi Amerika. Trump menilai bahwa hegemoni tersebut telah membatasi gerakan dan kemampuan Amerika untuk menjadi bangsa yang otonom dan dominan (Nichols, 2016). Kebijakan luar negeri Trump yang diwarnai oleh pengaruh isolasionis dan proteksionis ini sangat menekankan pentingnya cara pandang yang transaksional, yang lebih menekankan pada keuntungan finansial dan moneter bagi Amerika sebagai prioritas tertinggi daripada modal politik maupun keamanan (Ellis, dkk, 2016).

\section{Ekonomi dan Perdagangan Internasional}

Amerika Serikat di bawah kepemimpinan Trump akan mendapati beragam masalah dan tantangan yang tidak mudah dalam politik domestik dan hubungan internasionalnya. Salah satu isu utama yang harus segera mendapatkan perhatian segera oleh Trump adalah ekonomi dan perdagangan internasional. Trump seringkali mengaitkan isu ini dengan permasalahan imigran dan perdagangan bebas, yang ia sebut sebagai dua faktor bagi tingginya angka pengangguran di Amerika. Ia meyakini bahwa 
penyelesaian atas dua masalah ini akan membawa Amerika Serikat untuk membangun ekonomi yang lebih besar: "If we do what we have to do correctly, we can create the biggest economic boom in this country since the New Deal when our vast infrastructure was first put into place. It's a no-brainer. It's so obvious that even the Democrats can figure it out." (Trump, 2016: 125).

Salah satu kerja sama ekonomi yang hingga kini masih menjadi perdebatan adalah TPP yang proses negosiasinya telah dimulai pada masa pemerintahan Presiden Barack Obama. Mengulang janji kampanyenya, Trump tampaknya akan mengeliminasi TPP - dan mungkin juga NAFTA, yang ia anggap tidak dapat memberikan keuntungan ekonomi yang diharapkan. Bagi Trump, TPP akan menjadi "pukulan mematikan bagi usaha manufaktur Amerika;" ia juga memprioritaskan kepentingan luar negeri negara lain daripada ekonomi Amerika sendiri. Trump mengatakan: "Not only will the TPP undermine our economy, but it will undermine our independence ... There is no way to 'fix' the TPP. We need bilateral trade deals. We do not need to enter into another massive international agreement that ties us up and binds us down." (Trump, 2016a). Selain TPP, proyek kerja sama ekonomi lain yang saat ini masih dalam proses negosiasi dan terancam gagal dengan terpilihnya Trump adalah Transatlantic Trade and Investment Partnership (TTIP).

Proyeksi ini selaras dengan prinsip Trump yang tidak setuju akan perdagangan bebas. Trump berjanji untuk mengubah tata perdagangan internasional agar lebih berpihak pada Amerika Serikat: "Trade reform and the negotiation of great trade deals is the quickest way to bring our jobs back to our country... A Trump administration will change our failed trade policies, and I mean quickly." (Fox, 2016). Dengan ketergantungan negara mitra terhadap pasar Amerika yang lebih besar dibandingkan sebaliknya, serta dukungan kebijakan seperti Trade Expansion Act of 1962 dan Trade Act of 1974 yang dapat digunakan untuk membatasi dan memperbesar tarif, rencana Trump bukanlah sesuatu yang mustahil untuk terwujud (Davis, 2016).

Namun demikian, bila rencana ekonomi dan perdagangan yang diajukan oleh Trump selama kampanye benar-benar diwujudkan, akan berisiko memperburuk perekonomian dalam negeri dan hubungan Amerika Serikat dengan negara lain. Dengan menutup akses perdagangan bebas dan memutus hubungan kerja sama ekonomi, diperkirakan 7\% persen lapangan pekerjaan dan 14\% GDP (Gross Domestic Product) Amerika Serikat yang tergantung pada ekspor akan menjadi korban. Selain itu, global supply chain murah dapat terjadi karena perdagangan bebas, sehingga memutus perdagangan bebas sama artinya dengan juga memutus jaringan tersebut. Sekalipun proses manufaktur di dalam negeri mampu menciptakan lapangan pekerjaan, harga barang akan menjadi lebih mahal karena ongkos yang dibutuhkan lebih besar, yang kemudian dapat berujung pada meningkatnya inflasi dan hutang negara (White, 2016). Ditambah dengan pemotongan pajak yang juga direncanakan Trump, Amerika Serikat akan menanggung utang dan beban ekonomi yang jauh lebih besar (The Economist, 2016).

\section{Keamanan Nasional}

Sebelum menganalisis proyeksi kebijakan keamanan nasional Trump, khususnya yang berhubungan dengan terorisme, penting untuk memahami dua identitas utama Amerika Serikat, yaitu exemplar exceptionalism dan missionary exceptionalism. Exemplar exceptionalism merujuk pada Amerika Serikat sebagai tempat yang bebas dari kesalahan-kesalahan dunia (khususnya Eropa) dalam bidang sosial, politik, dan ekonomi (Greene, 1993: 58). Sementara itu, missionary exceptionalism merujuk pada Amerika Serikat yang menjalankan manifest destiny, imperialis, internasionalis, dan "leader of the free world" (McCrisken, 2002: 63). Apabila ditranslasikan menjadi bentuk kebijakan luar negeri, kedua paham eksepsionalisme ini mendorong Amerika Serikat ke arah yang benar-benar berbeda. Bila exemplar exceptionalism mendorong Amerika Serikat untuk menjalankan kebijakan luar negeri yang lebih isolasionis dengan hanya memfokuskan pada dirinya sendiri, missionary exceptionalism lebih menekankan pada bagaimana Amerika Serikat harus menjadi aktor 
internasional dan menginspirasi dunia dengan habits of democracy-nya (Kagan, 1998: 27). Trump agaknya akan mengarah pada isolasionis atau exemplar exceptionalism. Hal ini dapat dilihat melalui tiga janji kebijakan utamanya terkait keamanan nasional: penghacuran ISIS secara menyeluruh, modernisasi militer, dan perlakuan khusus bagi komunitas Muslim.

Untuk mengalahkan ISIS, meskipun Trump menyebutkan bahwa dia akan membutuhkan bantuan dari sekutu AS di Timur Tengah, ada kecendrungan bahwa Amerika Serikat akan bertindak sendiri menggunakan kekuatan militernya. Tujuan dari penghancuran ISIS ini adalah untuk menjaga keamanan nasional Amerika Serikat dari serangan terorisme. Trump akan menghentikan intervensi pada pemerintahan tertentu di Timur Tengah dan berfokus pada penghancuran ISIS. Potensi hilangnya intervensi Amerika Serikat di Timur Tengah semakin menunjukan bahwa Trump tidak tertarik pada ide-ide missionary exceptionalism dan justru semakin condong ke arah isolasionisme yang mementingkan keamanan domestiknya.

Trump akan menambah kekuatan militer untuk mempertahankan Amerika dari serangan eksternal. Trump akan memulai modernisasi militernya dengan meningkatan anggaran belanja militer, yang mulanya 3\% dari total Pendapatan Domestik Bruto (PDB) hingga maksimum $6,5 \%$, seperti yang pernah ia tulis dalam buku The American We Deserve (Trump, 2002: 149). Selain itu, Trump juga akan memodernisasi sistem pertahanan misil balistik. Hal yang penting untuk dipahami dalam kebijakan Trump ini adalah bahwa kekuatan militer baru hanya akan digunakan untuk dua hal, yaitu menghancurkan ISIS dan mempertahankan Amerika dari serangan tradisional maupun nontradisional, bukan untuk membantu sekutu Amerika (Trump, 2016). Bila ini benar-benar terwujud, intervensi militer Amerika Serikat di dunia internasional diproyeksikan akan berkurang, yang menunjukkan bahwa negara ini bergerak menuju isolasionisme.

Akan halnya perlakuan khusus terhadap komunitas Muslim, Trump akan memberlakukan prosedur penyaringan dan pencatatan khusus bagi mereka sebagai implikasi dari janji kampanye yang akan melarang Muslim memasuki Amerika Serikat. Ini merupakan wujud dari kebijakan utama Trump dalam menangkal terorisme di Amerika Serikat.

Kemungkinan kebijakan ini akan terealisasi menjadi lebih besar, mengingat Trump baru saja menunjuk Frank Gaffney yang terkenal dengan posisi antimuslimnya dan Steve Bannon yang sangat mendukung white supremacy sebagai bagian dari administrasinya (Maltz, 2016). Kebijakan Trump pada komunitas Muslim inilah yang paling menegaskan posisi Trump sebagai exemplar exceptionalism. Amerika Serikat di bawah kepemimpinan Trump akan benar-benar menjadi "city on a hill," di mana ia akan menutup diri dari pengaruh budaya lain dan pengakuan pada pembangunan yang dipimpin oleh bangsa pilihan, yaitu masyarakat kulit putih Amerika Serikat.

\section{NATO dan Rusia}

Posisi Trump pada NATO sangatlah sederhana dan singkat. Amerika Serikat tidak lagi bersedia untuk membiayai NATO dengan skema yang berlaku pada saat ini. Trump selalu menegaskan bahwa ia menginginkan sekutu-sekutu Amerika Serikat untuk berkontribusi lebih, baik secara militer maupun pendanaan. Sejak NATO berdiri enam dekade silam, skema pembiayaannya tidak pernah berubah, yaitu Amerika Serikat selalu membiayai 70\% dana operasionalnya (Machon, 2016). Anggota-anggota lain dari NATO akan "terpaksa" untuk bersedia berkontribusi lebih sehingga Amerika Serikat tetap bertahan dalam aliansi. Kemungkinan sebaliknya sangat sukar untuk terjadi karena Eropa belum mampu menghadapi berbagai masalah keamanan regional, termasuk Presiden Rusia Vladimir Putin, tanpa bantuan AS (Wallace, 2001).

Bila skenario ini (negara-negara sekutu menambah porsi pembiayaan mereka) terjadi, kewenangan Amerika Serikat dalam menentukan agenda NATO ke depan akan berkurang. Kekuasaan Amerika Serikat mungkin akan bergeser ke beberapa negara-negara Eropa Barat - memungkinkan bagi sebuah pax 
germanica atau kepemimpinan Jerman di NATO (Hockenos, 2016). Amerika Serikat mungkin tidak akan memiliki kekuasaan seluas dulu, khususnya dalam konteks tata kelola dan bagaimana NATO merespon permasalahan dunia.

Turunnya dominasi AS dalam NATO bukan berarti pengaruhnya akan hilang sama sekali. Amerika Serikat mungkin akan tetap memainkan beberapa peran penting dalam memutuskan posisi NATO di dunia. Meskipun anggota-anggotanya mungkin akan siap untuk berkontribusi lebih, NATO tetap mengharapkan kehadiran Amerika Serikat sebagai pemimpin (Hague, 2016). Situasi inilah yang dinilai justru akan semakin membahayakan posisi Eropa, mengingat Trump cenderung untuk lebih kooperatif dengan Rusia (Machon, 2016). Sebagai contoh, Trump tidak begitu peduli dengan aneksasi Rusia di Krimea yang notabene adalah pertahanan terakhir Eropa Barat terhadap pengaruh Rusia. Meskipun Eropa mungkin akan berkontribusi lebih, Amerika Serikat masih memiliki kekuatan militer yang besar dan melalui kekuatan relatif itu maka ia akan mampu mempengaruhi posisi NATO terkait Rusia. Kekuasaan Amerika Serikat mungkin akan cenderung turun di Eropa Barat apabila Trump tetap menjalankan rencana kebijakannya ini.

Hubungan dengan Rusia sendiri merupakan salah satu isu yang paling terpolarisasi dalam pemilihan tahun 2016 ini. Menyebut Putin sebagai pemimpin yang lebih baik dari Obama, Trump secara terbuka menyampaikan aspirasi untuk memulai hubungan diplomatis yang lebih bersahabat dengan Rusia, terutama dalam isu keamanan nasional dan kontraterorisme (East, 2016). Ditingkahi oleh tuduhan pemerintah AS bahwa Rusia berada di balik peretasan server email Democratic National Committee - yang segera disangkal oleh Putin - Trump sendiri tidak membantah adanya peran dan stake Rusia di pemilihan kali ini. Ini semua mendorong Clinton menyebut Trump sebagai "boneka [Rusia]" dalam debat presidensial yang ketiga. Rusia tampaknya akan jauh lebih mudah mengendalikan Amerika Serikat di bawah Trump dibandingkan Clinton.
Trump pernah berujar, "We desire to live peacefully and in friendship with Russia and China. We have serious differences with these two nations, and must regard them with open eyes, but we are not bound to be adversaries. We should seek common ground based on shared interests." (The New York Times, 2016). Upaya Trump untuk memperbaiki hubungan dengan Rusia mungkin tidak akan mendapatkan dukungan yang besar dari Kongres, sekalipun Kongres didominasi oleh Partai Republik. Membutuhkan waktu lama dan usaha yang besar bagi terjadinya perbaikan hubungan antara Amerika Serikat dan Rusia, dengan atau tanpa Donald Trump sebagai presiden. Saat ini tampak bahwa janjinya untuk memperbaiki hubungan dengan Rusia hanya didasarkan pada sentimen, rasa hormat dari seseorang kepada kepala negara Rusia yang seperti dirinya, menyelesaikan masalah dengan menggunakan machismo dan intimidasi.

\section{Amerika Latin}

Trump akan memulai masa jabatannya dalam periode yang konfliktual dalam politik Amerika Latin, khususnya menyangkut keberadaan gerakan politik yang bernama pink tide. ${ }^{3}$ Sebagian besar pemimpin pink tide memiliki kesamaan dalam pandangan politik mereka: populisme, kemerdekaan politik dan ekonomi, serta penolakan terhadap neoliberalisme dan intervensionisme Amerika Serikat. Penolakan yang meluas atas ide Trump untuk membangun tembok di perbatasan dengan Meksiko mencerminkan kesulitan besar yang akan ditemui Trump di kawasan ini.

Dewasa ini, kombinasi dari berbagai faktor, seperti skandal korupsi dan persepsi rakyat bahwa para pemimpin pink tide gagal mewujudkan janji mereka, telah mendorong konsensus bahwa pink tide sedang menurun (The Economist, 2015). Di satu sisi, melemahnya pink tide akan memudahkan tugas Trump dalam menjaga hubungan diplomatis yang baik dengan tetangga-tetangga mereka di selatan. Namun di sisi lain, jika mengingat betapa kontroversialnya Trump, boleh jadi ia akan mengakibatkan berkembangnya kembali gerakan tersebut (TeleSUR, 2016). Jika Trump mempertahankan posisi dia selama kampanye dan 
mengurangi intervensi Amerika Serikat di skala global, maka akan ada dampak secara drastis ke Amerika Latin. Kebijakan proteksionis Trump berpotensi merugikan negara-negara yang selama ini mendapatkan bantuan dari AS, seperti Kolombia. Janji Trump untuk mundur dari perdagangan bebas dapat berdampak pada NAFTA, berikut investasi dan lapangan kerja yang telah dibangun di Meksiko. Peningkatan halangan perdagangan dan restriksi imigrasi dapat menghambat aliran barang, jasa, dan tenaga kerja ke dalam Amerika Serikat, yang kelak akan berdampak negatif bagi perdagangan dan ekonomi negara-negara seperti Honduras, Guatemala, Ekuador, dan Peru (Castaneda, 2016).

Dalam skenario terbaik, Trump akan dapat mempertahankan status quo dan memanfaatkan konsolidasi ideologi kanan di Amerika Latin untuk keuntungan Amerika Serikat. Namun, jika Trump berusaha lebih keras untuk mempertahankan hegemoni di Amerika Latin, maka terdapat potensi untuk eskalasi konflik.

\section{Timur Tengah}

Donald Trump mengindikasikan bahwa ia mendukung one-state solution untuk konflik IsraelPalestina. Lebih jauh, ia juga menekankan pentingnya Israel dalam usaha counterterrorism terhadap "terorisme Islam radikal.” Meskipun dukungan yang disampaikan Trump terhadap Israel bukan merupakan hal baru, posisi yang akan ia ambil tersebut menunjukkan adanya perbedaan yang signifikan dari usaha diplomasi pemerintahan sebelumnya, sebagaimana ditunjukkan oleh Road Map (Faris, 2013: 73). Pendekatan Trump ini dapat mengubah secara signifikan proses diplomasi AS pada masa pemerintahannya.

Trump akan menjalankan politik luar negeri yang lebih keras terhadap teorisme dan rezim-rezim pemerintah yang menentang kepentingan AS di Timur Tengah. Ini tercermin dari ide-idenya untuk melawan ISIS, yang tidak bisa dijalankan bersamaan dengan melawan kekuatan militer Assad di Suriah karena akan menguras sumber daya AS. Jika AS harus terlibat lebih jauh lagi dalam konflik di Suriah, Trump tampaknya akan tetap mengandalkan kekuatan tempur udara, dengan bantuan dari Rusia dan negara-negara Arab. (Haberman \& Sanger, 2016).

Trump diproyeksikan akan menjalankan politik luar negeri yang cenderung reaktif terhadap dua kekuatan utama kawasan, Iran dan Arab Saudi. Dengan dukungan Kongres, Trump akan berupaya menegosiasi ulang atau bahkan membatalkan kesepakatan nuklir dengan Iran yang dicapai pada tahun 2015. Terhadap Arab Saudi, Trump pernah mengatakan, "We protect countries, and take tremendous monetary hits on protecting countries. I think if Saudi Arabia was without the cloak of American protection... I don't think it won't be around." (Haberman \& Sanger, 2016). Sejalan dengan kehendak agar Amerika mengurangi keterlibatan

internasionalnya, Trump sangat mungkin meminta Saudi untuk berkontribusi dalam memerangi ISIS dan mencegah kebangkitan Iran. Untuk itu, Trump mengatakan bahwa Arab Saudi dapat memiliki senjata nuklir. Situasi ini tentu akan membuat kawasan Timur Tengah akan semakin jauh dari stabil.

\section{Asia Timur}

Seperti halnya terhadap NATO, terhadap dua sekutu utamanya di kawasan, yaitu Jepang dan Korea Selatan, Trump juga akan mempertimbangkan untuk tidak lagi membela mereka kecuali mereka setuju untuk membayar Amerika Serikat lebih banyak. Tokyo dan Seoul akan diminta oleh Trump untuk mengambil tanggung jawab yang lebih besar dalam keamanan regional. Mereka bahkan disarankan untuk mendapatkan senjata nuklir mereka sendiri demi menghadapi ancaman dari Korea Utara. Bila ini terjadi, konsekuensi langsungnya adalah penurunan derajat hubungan antara Amerika Serikat dengan Jepang dan Korea Selatan.

Proteksionisme akan membawa Trump bersikap lebih keras kepada Cina. Negara dengan kekuatan ekonomi terbesar kedua di dunia ini dinilainya telah bertindak curang dan mendapatkan keuntungan lebih besar dalam hubungan perdagangan dengan Amerika Serikat (Trump, 2015). Meski demikian, dalam hal politik keamanan, Trump mungkin akan menjalankan 
kebijakan yang lebih lunak kepada Cina. Ia pernah mengatakan bahwa keamanan di Laut Cina Selatan harus dikembalikan kepada negara-negara yang berada di dalamnya - sebuah pernyataan yang menyiratkan pengakuan akan kekuatan militer Cina di kawasan tersebut (Haberman \& Sanger, 2016). Peran penting Cina akan dibutuhkan oleh Trump ketika ia harus mengambil langkah yang tepat dalam upayanya menyelesaikan krisis nuklir di Semenanjung Korea.

\section{KESIMPULAN}

Presiden-terpilih Trump diperkirakan akan menjalankan politik luar negeri dengan beberapa ciri yang menonjol. Pertama, Amerika Serikat cenderung menolak atau memandang dengan skeptis konsep keamanan kolektif maupun organisasi internasional. Kedua, Amerika akan menolak kompromi yang disyaratkan atau dimunculkan oleh kesepakatan atau kerja sama multilateral, karena kompromi merupakan bentuk kelemahan, khususnya ketika ia berdampak negatif pada kepentingan ekonomi domestik Amerika. Kemungkinan kebijakannya terhadap TPP, NAFTA, perdagangan dengan Cina, dan kesepakatan dengan Iran dapat mengafirmasi poin ini.

Ketiga, Trump dalam berbagai kesempatan juga dengan sangat jelas menonjolkan kebijakan luar negeri yang lebih isolasionis. Di bawah Trump, Amerika Serikat tampaknya tidak perlu lagi menjadi "polisi dunia”. Keterlibatan Amerika dalam berbagai konflik di dunia pada akhirnya memberikan dampak negatif bagi perekonomian Amerika. Trump akan menjadikan Amerika menahan diri dari terlibat dalam konflikkonflik internasional dan memfokuskan diri untuk membangun kekuatan di dalam negeri. Trump melihat intervensi Amerika di berbagai belahan dunia justru berdampak negatif pada relasi Amerika dengan berbagai negara besar, terutama Rusia dan Cina. Meski demikian, pendekatan isolasionis Trump tidak selamanya didasari murni oleh oposisinya terhadap intervensionisme, namun juga oleh perhitungan transaksional ekonomi yang pragmatis. Dengan kata lain, penentangan Trump terhadap berbagai bentuk intervensi Amerika disebabkan oleh kegagalan pemerintah untuk mendapatkan kemenangan yang besar maupun keuntungan ekonomi yang nyata dari intervensi tersebut.

Keempat, dan terakhir, kebijakan isolasionis Trump juga diwarnai oleh posisi "garis keras" terkait dengan imigrasi. Trump melihat bahwa kebijakan imigrasi Amerika sekarang terlalu longgar dan menimbulkan banyak masalah; imigran ilegal dan pengungsi adalah permasalahan bagi Amerika. Imigran ilegal dari Meksiko dianggap sebagai membawa potensi peningkatan tingkat kriminalitas di Amerika, sementara imigran dan pengungsi dari negara-negara yang mayoritas beragama Islam dilihat sebagai kelompok yang berisiko tinggi terlibat terorisme.

Dengan terpilihnya Trump sebagai presiden Amerika masyarakat dunia harus mempersiapkan diri dengan politik luar negeri yang berlawanan dengan kebijakan umum Amerika Serikat selama ini. Amerika Serikat akan menjadi lebih isolasionis dan proteksionis, berfokus pada pengetatan pengawasan atas batas-batas negara, menerapkan imigrasi yang lebih selektif dan ketat, menempatkan prioritas pada ekonomi domestik, membatasi keterlibatan dalam konflik yang berkepanjangan di banyak tempat, dan mengurangi komitmen internasional - ini semua adalah wujud dari exemplar execptionalism yang menjadi prinsip dasar politik luar negeri Trump.

\section{CATATAN AKHIR}

$1 \quad$ Pada masa pemerintahan pertamanya, Reagan dikenal sangat "hawkish," menjalankan politik luar negeri yang agresif, antikomunis dan sangat mengandalkan kekuatan militer, khususnya dalam hubungan antara Amerika Serikat dengan Amerika Tengah dan Uni Soviet. Posisi ini ternyata dinilai sebagai tidak menguntungkan bagi Reagan yang berkampanye untuk masa jabatan kedua pada pemilihan di tahun 1984. Sebagai bagian dari strateginya memenangkan pemilihan, Reagan beralih dari sikap keras menuju "conciliatory foreign policy positions," terutama terhadap Uni Soviet. Terpilih kembali untuk masa jabatan kedua, Reagan tidak surut langkah; ia tetap mengurangi kadar "hawkism" dalam politik luar negerinya, tidak kembali menjadi agresif seperti pada masa jabatan pertamanya.

2 Misalnya, pada tahun 2002, ketika masih menjabat sebagai senator, Hillary memberikan suaranya guna mengotorisasi penggunaan militer untuk menyerang Irak. Saat menjabat sebagai menteri luar negeri Hillary merupakan pendukung "perubahan rejim" di Libya. Hillary jugalah yang memerintahkan keterlibatan pasukan khusus 
Angkatan Laut (U.S. Navy Seal) untuk menggerebek Abbotabat, Pakistan, pada tahun 2011. Misi ini 'berhasil' membunuh tersangka teroris 11 September, Osama bin Laden.

3 Pink tide merupakan nama tidak resmi yang diberikan kepada tren yang sempat melanda Amerika Latin di mana publik cenderung bersimpati kepada gerakan dan pemimpin politik yang menyuarakan ide-ide quasi-sosialis: bukan merah sepenuhnya, tetapi merah muda. Tren tersebut ditandai oleh bangkitnya pemimpin-pemimpin seperti Hugo Chavez di Venezuela, Evo Morales di Bolivia, serta Nestor dan Cristina Kirchner di Argentina.

\section{REFERENSI}

\section{JURNAL}

Aldrich, John, Sullivan, John \& Borgida, Eugene. 1989. Foreign Affairs and Issue Voting: Do Presidential Candidates "Waltz Before a Blind Audience?". American Political Science Review, March, Vol. 83, No. 1.

Anand, Sowmya \& Krosnick, Jon. 2003. The Impact of Attitudes toward Foreign Policy Goals on Public Preferences among Presidential Candidates: A Study of Issue Publics and the Attentive Public in the 2000 U.S. Presidential Election. Presidential Studies Quarterly, March, Vol. 33, No. 1.

Gadarian, Shana. 2010. Foreign Policy at the Ballot Box: How Citizens Use Foreign Policy to Judge and Choose Candidates. The Journal of Politics, October, Vol. 72, No. 4.

Hurwitz, Jon \& Peffley, Mark. 1987. The Means and Ends of Foreign Policy as Determinants of Presidential Support. American Journal of Political Science, May, Vol. 31, No. 2.

Kagan, Robert. 1998. The Benevolent Empire. Foreign Policy, No. 111. Karol, David \& Miguel, Edward. 2007. The Electoral Cost of War: Iraq Casualties and the 2004 U.S. Presidential Election. Journal of Politics, August, Vol. 69, No. 3.

McCrisken, Trevor. 2002. Exceptionalism. Dalam Alexander DeConde et al. (eds.). Encyclopedia of American Foreign Policy, Vol. 2, 2nd ed. New York: Scribner.

Merolla, Jennifer, Ramos, Jennifer \& Zechmeister, Elizabeth. 2007. Crisis, Charisma, and Consequences: Evidence from the 2004 U.S. Presidential Election. Journal of Politics, February, Vol. 69, No. 1.

Nincic, Miroslav \& Hinckley, Barbara. 1991. Foreign Policy and the Evaluation of Presidential Candidates. The Journal of Conflict Resolution, June, Vol. 35, No. 2.

Randolph, Christopher, Jr. 2006. The Effects of Electoral Concerns on Presidential Foreign Policy: The Case of Ronald Reagan. Vanderbilt Undergraduate Research Journal, Spring, Vol. 2, No. 1.

Wallace, William. 2001. Europe, the Necessary Partner. Foreign Affairs, May/June, Vol. 80, No. 3.

\section{BUKU}

Faris, Hani. 2013. The Failure of the Two-state Solution: The Prospect of One State in the Israel-Palestinian Conflict. London \& New York: I.B. Tauris.

Greene, Jack. 1993. The Intellectual Construction of America: Exceptionalism and

Identity from 1492-1800. Chapel Hill: University of North Carolina
Press.

Trump, Donald. 2002, The America We Deserve. New York: Renaissance Books.

Trump, Donald. 2016b. Great Again: How to Fix Crippled America. New York: Simon and Schuster.

\section{WEBSITE:}

Beckwith, Ryan. 2015. Transcript: Read Hillary Clinton's Speech on Fighting ISIS. Time (daring). 19 November. (http://time.com/ 4120295/hillary-clinton-foreign-policy-isis/, diakses pada $14 \mathrm{Juli}$ 2016).

Beckwith, Ryan. 2016. Read Donald Trump's 'America First' Foreign Policy Speech. Time (daring). 27 April. (http://time.com/4309786/ read-donald-trumps-america-first-foreign-policy-speech/, diakses pada 14 Juli 2016).

Berman, Russell. 2015. Donald Trump's Call to Ban Muslim Immigrants. The Atlantic (daring). 27 December. (http://www.theatlantic.com/ politics/archive/2015/12/ donald-trumps-call-to-ban-muslimimmigrants/419298/, diakses pada 26 Juli 2016).

Brunnstrom, David. dkk. 2016. Trump Vows To Improve Relations With Russia, China If Elected U.S. President. The Huffington Post (daring). 27 April. (http://www.huffingtonpost.com/entry/trumpforeign_policy_us_5720f9d7e4b01a5ebde42eee), diakses pada 26 Juli 2016)

Castaneda, Jorge. 2016. The Trump Shock in Latin America. Project Syndicate (daring). 11 November (https://www.projectsyndicate.org/commentary/donald-trump-latin-america-by-jorgeg-casta-eda-2016-11, diakses pada 15 November 2016).

Clinton, Hillary. 2011. America's Pacific Century. Foreign Policy (daring). 11 October. (http://foreignpolicy.com/2011/10/11/ americas-pacific-century/, diakses 13 Juli 2016).

Clinton, Hillary. 2015a. Hillary Clinton Statement on Trans-Pacific Partnership. Hillary Clinton (daring). 7 October. (https:// www.hillaryclinton.com/briefing/statements/2015/10/07/transpacific-partnership/, diakses pada 24 Juni 2016).

Clinton, Hillary. 2015b. Nationa/ Security: With Policies that keep us Strong and Safe, America can lead the World in the 21st Century. Hillary Clinton (daring). 13 June. (https://www.hillaryclinton.com/ issues/national-security/> , diakses pada 24 Juni 2016).

CNN. 2016. 2016 election results - presidential results (daring). (http:/ /edition.cnn.com/election/results, diakses pada 20 November 2016).

Davis, Bob. 2016. Donald Trump Will Need to Leverage Size, Power of U.S. Economy to Remake Global Trading System. Washington Street Journal (daring). 9 November. (http://www.wsj.com/articles/ donald-trump-will-need-to-leverage-size-power-of-u-s-economyto-remake-global-trading-system-1478701144, diakses pada 13 November 2016).

DHS Press Office. 2016. Joint Statement from the Department Of Homeland Security and Office of the Director of National Intelligence on Election Security. Homeland Security (daring). 7 October. (https://www.dhs.gov/news/2016/10/07/joint-statementdepartment-homeland-security-and-office-director-national, diakses pada 2 November 2016).

Diamond, Jeremy \& Collinson, Stephen. 2016. Donald Trump's foreign policy: 'America first.' CNN (daring), 27 April. (http:// 
edition.cnn.com/2016/04/27/politics/donald-trump-foreign-policyspeech/>, diakses pada 26 Juli 2016).

East, Kristen. 2016. Trump in Hot Water Over Putin Embrace. Politico (daring). 9 September. (http://www.politico.com/story/2016/09/ trump-putin-embrace-fallout-227940, diakses pada 4 November 2016).

Ellis, Sam. dkk. 2016. How Donald Trump thinks about foreign policy, explained in 7 minutes. Vox (daring). 1 November. (http:// www.vox.com/world/2016/11/1/13481594/donald-trumpexplained-foreign-policy, diakses pada 16 November 2016).

Fox, Michelle. 2016. One trade war and Donald Trump's economy is dead, market expert says. CNBC (daring). 11 November. (http:// www.cnbc.com/2016/11/11/one-trade-war-and-donald-trumpseconomy-is-dead-market-expert-says.html, diakses pada 13 November 2016).

Haberman, Maggie \& Sanger, David. 2016. Transcript: Donald Trump Expounds on His Foreign Policy Views. The New York Times (daring). 26 March. (http://www.nytimes.com/2016/03/27/us/ politics/donald-trump-transcript.html? $r=0$, diakses pada 10 November 2016).

Hague, William. 2016. After Donald Trump's victory, Europe and the US Must Stand Together: or The West will Fall. The Telegraph (daring). 14 November. (http://www.telegraph.co.uk/news/2016/ 11/14/after-donald-trumps-victory-europe-and-the-us-must-standtogethe/, diakses pada 17 November 2016).

Hockenos, Paul. 2016. The Dawn of Pax Germanica. Foreign Policy (daring). 14 November. (http://foreignpolicy.com/2016/11/14/thedawn-of-pax-germanica-angela-merkel-donaldtrump/, diakses pada 17 November 2016).

Jewish Telegraphic Agency. 2016. Hillary Clinton: US has 'Moral Obligation' to support Israel. (daring). 2 June. (http://www.jta.org/ 2016/06/02/news-opinion/politics/ hillary-clinton-us-has-moralobligation-to-support-israel-donald-trump-temperamentally-unfit, diakses pada 23 Juni 2016).

Kessler, Glenn. 2016. Trump's Claim that the U.S Pays 'Lion's Share' for NATO. The Washington Post (daring). 30 March. (https:// www.washingtonpost.com/news/fact-checker/wp/2016/03/30/ trumps-claim-that-the-u-s-pays-the-lions-share-for-nato/> , diakses pada 26 Juli 2016).

Kleiner, Sam. 2016. With his Finger on the Trigger. The Atlantic (daring). 3 June. (http://www.theatlantic.com/international/archive/ 2016/06/donald-trump-nuclear-weapons/485504/, diakses pada 26 Juli 2016)

Machon, Annie. 2016. NATO or not NATO - The Question for Donald Trump. Russiantoday.com (daring). 15 November. (https:// www.rt.com/op-edge/367014-nato-us-europe-trump/, diakses pada 16 November 2016).

Maltz, Judy. 2016. Islamophobe and 'Great Friend of Israel' Frank Gaffney Reportedly Joining Trump Team. Haaretz (daring). 16 November. (http://www.haaretz.com/world-news/u-s-election2016/.premium-1.753512, diakses 16 November 2016).

Milbank, Dana. 2016. For Trump, it's (white) America First. The Washington Post (daring). 15 July. (https:// www.washingtonpost.com/opinions/for-donald-trump-its-whiteamerica-first/2016/07/15/4faa1b60-49f9-11e6-90a8fb84201e0645_story.html>, diakses pada 26 Juli 2016).
Nechepurenko, Ivan. 2015. Hillary Clinton as U.S. President 'Wouldn't Fix' Russia-U.S. Relationship. The Moscow Times (daring). 13 April. (http://www.themoscowtimes.com/articles/hillary-clinton-as-uspresident-wouldnt-fix-russia-us-relationship-45715, diakses pada 18 Juli 2016).

Nichols, Christopher. 2016. Trump's Misguided and Empty Promise of Protectionism Dovetails with His Appeal to Isolationism. History News Network (daring). 17 April. (http://historynewsnetwork.org/ article/162423, diakses pada 15 November 2016).

Noland, Marcus. dkk. 2016. Assessing Trade Agendas in the US Presidential Campaign. Peterson Institute for International Economics (daring). September. (https://piie.com/publications/piiebriefings/ assessing-trade-agendas-us-presidential-campaign, diakses pada 30 Oktober 2016)

NPR. 2016a. Clinton Plays Up Her Foreign Policy Experience; Portrays Trump As Unfit (daring). 3 June. (http://www.npr.org/2016/06/03/ 480564688/clinton-plays-up-her-foreign-policy-experienceportrays-trump-as-unfit, diakses pada 18 Juli 2016).

NPR. 2016b. Fact Check: Trump And Clinton Debate For The First Time (daring). 26 September 2016. (http://www.npr.org/2016/09/ 26/495115346/fact-check-first-presidential-debate, diakses pada 29 Oktober 2016)

NPR. 2016c. Fact Check: Clinton And Trump Debate For The 2nd Time (daring). 9 October 2016. (http://www.npr.org/2016/10/09/ 497056227/fact-check-clinton-and-trump-debate-for-the-secondtime, diakses pada 29 Oktober 2016).

Putz, Catherine. 2015. What Might a Hillary Clinton Presidency Mean for Asia? The Diplomat (daring). 13 April. (http://thediplomat.com/ 2015/04/what-might-a-hillary-clinton-presidency-mean-for-asia/> , diakses pada 23 Juni 2016).

Saad, Lydia. 2016. Clinton Wins Third Debate, Gains Ground as 'Presidential.' Gallup (daring). 21 October. (http://www.gallup.com/ poll/196643/clinton-wins-third-debate-gains-groundpresidential.aspx??__source=EEECTION_2016\&g_medium=topic\&g_campaign=tiles, diakses pada 1 November 2016).

Stacey, Jeffrey. 2016. The Hillary Clinton Doctrine. Foreign Affairs (daring). 17 May. (https://www.foreignaffairs.com/articles/2016-0517/hillary-clinton-doctrine>, diakses pada 11 Juli 2016).

TeleSUR. 2016. Correa Says Trump Could Revitalize Latin America's Left (daring). (http://www.telesurtv.net/english/news/Correa-SaysTrump-Could-Revitalize-Latin-Americas-Left-20160727-0022.html, diakses pada 14 November 2016).

The Economist. 2015. The Ebbing of the Pink Tide (daring). 28 November. (http://www.economist.com/news/leaders/21679192mauricio-macris-remarkable-victory-will-reverberate-across-southamerica-ebbing-pink, diakses pada 4 November 2016).

The Ecnonomist. 2016. Trump and the economy: Strap up (daring). 12 November. (http://www.economist.com/news/united-states/ 21710013-congress-can-constrain-only-parts-donald-trumpseconomic-policy-strap-up, diakses 13 November 2016).

The New York Times. 2016. Transcript: Donald Trump's Foreign Policy Speech (daring). 27 April. (http://www.nytimes.com/2016/04/28/ us/politics/transcript-trump-foreign-policy.html, diakses pada 15 November 2016).

Trump, Donald. 2015. Trade. Donald J. Trump (daring). (https:// www.donaldjtrump.com/policies/trade, diakses pada 13 November 
2016).

Trump, Donald. 2016a. Declaring American Economic Independence (daring). (https://assets.donaldjtrump.com/

DJT DeclaringAmericanEconomiclndependence.pdf, diakses pada 14 November 2016).

Trump, Donald. 2016c. Foreign Policy and Defeating ISIS.

Donaldjtrump.com (daring). (https://www.donaldjtrump.com/ policies/foreign-policy-and-defeating-isis/> , diakses pada 15 November 2016).

White, Martha. 2016. Trump Trade Policy Ideas Could Trigger Recession, Stagflation, Economists Say. NBC News (daring). 10 November. (http://www.nbcnews.com/business/economy/trumptrade-policy-ideas-could-trigger-recession-stagflation-economistssay-n682221, diakses pada 13 November 2016).

Zenko, Micah. 2016. Hillary the Hawk: A History. Foreign Policy (daring). 27 July. (http://foreignpolicy.com/2016/07/27/hillary-thehawk-a-history-clinton-2016-military-intervention-libya-iraq-syria/, diakses pada 10 November 2016). 